\title{
Aspirin and the Kidney
}

\author{
New Zealand Rheumatism Association Study
}

British Medical fournal, 1974, 1, 593-596

\section{Summary}

A survey of 763 patients with rheumatoid arthritis and 145 with osteoarthritis in six clinics in New Zealand showed no association between aspirin intake and a score designed to detect analgesic nephropathy. Analgesic nephropathy was diagnosed clinically in three patients taking APC (aspirin, phenacetin, and caffeine or codeine or both) and in one who took aspirin and phenylbutazone and was suspected in one who took aspirin and paracetamol. Isolated aspirin was not implicated. The study showed that most people can take large quantities of salicylates without renal injury.

The findings are, however, consistent with the view that there is a risk from APC compounds taken in large quantity, but the numbers at risk in this study were small. Aspirin may have an additive effect with other analgesics in causing renal damage. An increased frequency of urinary tract symptoms in those taking analgesics requires further investigation.

\section{Participants in the study were: D. E. Caughey, Auckland; I. C. Isdale, Rotorua; J. M. Tweed and B. L. J. Treadwell, Wellington; J. K. Laing and J. Kirk, Christchurch; T. C. Highton and D. G. Palmer, Dunedin; R. D. Wigley, Palmerston North (co-ordinator); R. B. Morrison, Welling- ton (nephrologist); K. Couchman and B. Reay (data analysis); Mrs. M. Fowles and Mrs. E. Caughey (data collection).}

\section{Introduction}

As the salicylates are accepted as basic treatment for rheumatoid anthritis members of the New Zealand Rheumatism Association became concerned by reports in the medical (Royal Australasian College of Physicians, 1969) and lay press of damage to the kidney from aspirin. These reponts were based on uncontrolled observations of renal clinic patients and studies of dehydrated rats (Nanra and Kincaid-Smith, 1970). Our impression had been that it was rare for aspirin alone to damage the kidney in anthritis cases in New Zealand. This study was undentaken to determine whether such a problem existed in patients treated with salicylates under New Zealand conditions. The plan of the study and a review of the literature have already been published (Wigley, 1971). When related to the amount of aspirin consumed in the Western World, 30 tons $(30,500 \mathrm{~kg})$ a year in New Zealand (Consumer, 1972), the small number of published cases in which renal disease had been attributed to aspirin alone might have been below coincidence level. No further adequately documented reponts have appeared since that review was published.

Surveys of samples drawn from populations other than those of renal clinios allow more objective assessment of risk as they include control cases. These provide evidence that compound preparations of aspirin, phenacetin, and caffeine or codeine or both (APC) cause renal disease but do not suppont the contention that aspirin alone can cause nephropathy (table I).

\section{Plan of Study}

To determine whether aspirin either alone or in APC preparations or together with other anti-inflammatory drugs could cause renal disease, data were collected from rheumatoid anthritis and osteoanthritis patients attending six rheumatic disease clinics. Consecutive cases were taken to avoid selection of cases with renal disonder. As numerous anti-inflammatory drugs would have been given, with wide variation of total dose, large numbers of cases would be necessary to ensure subgroups large enough for analysis. The first 470 cases were predominantly ones of longstanding, with a drop in age, duration, dosage, and severity thereafter. It became clear that substantially larger numbers would be required if funther information of value was to be obtained. As this course was impracticable the study was closed on 31 December 1972 (table II).

A data sheet was used to record the features shown in tables II to V. Concentration tests and pyelography were undertaken if the initial screening showed an abnormality.

The average daily drug dosage was assessed for each drug group from patients' recall in addition to prescription records. Class one indicated no drug or occasional dosage not exceeding two tablets a day and class two indicated an intermittent past dosage of more than two tablets daily. Both of these classes of patients were grouped in the final analysis with those who had had no drug. Class three was for continuous drug 
TABLE I-Summary of Population Samples that have been studied showing Relation of Analgesic Intake to Renal Diseas?

\begin{tabular}{|c|c|c|c|c|c|c|c|}
\hline \multirow{2}{*}{ Authors } & \multirow{2}{*}{ Sample } & \multirow{2}{*}{$\begin{array}{l}\text { Total } \\
\text { No. } \\
\text { Screened }\end{array}$} & \multicolumn{4}{|c|}{ Analgesics } & \multirow{2}{*}{ Findings } \\
\hline & & & Aspirin & $\begin{array}{l}\text { APC and/or } \\
\text { Aspirin }\end{array}$ & APC & Nil & \\
\hline $\begin{array}{l}\text { Sorensen, } 1966 \\
\text { (Denmark) }\end{array}$ & $\begin{array}{l}\text { Rheumatoid arthritics } \\
\text { Inpatients } \\
\text { Rheumatoid arthritics } \\
\text { Pyelograms }\end{array}$ & $\begin{array}{r}244 \\
2,200 \\
32 \\
976\end{array}$ & & $\begin{array}{r}134 \\
17 \\
160\end{array}$ & 123 & $\begin{array}{c}110 \\
\text { Matched } \\
5 \\
816\end{array}$ & $\begin{array}{l}\text { N.S. } \\
\text { N.S. Bacteriuria } \\
\text { N.S. Biopsies } \\
\text { Significant }\end{array}$ \\
\hline $\begin{array}{l}\text { Dubach et al., } 1971 \\
\text { (Switzerland) }\end{array}$ & Factory women & 7,311 & & & 623 & 621 & $\begin{array}{l}\text { Significant for protein, S.G., and urinary } \\
\text { symptoms }\end{array}$ \\
\hline Lawson, 1973 & Inpatients, international & 6,407 & 307 & 461 & 114 & 5,946 & $\begin{array}{l}\text { N.S. except for women over } 60 \text { with } \\
\text { haematuria }\end{array}$ \\
\hline $\begin{array}{l}\text { Waters et al., } 1973 \\
\text { Present study N.Z.R.A. }\end{array}$ & $\begin{array}{l}\text { Population, Wales } \\
\text { Patients with rheumatoid } \\
\text { and osteoarthritis }\end{array}$ & $\begin{array}{r}3,000 \\
908\end{array}$ & $\begin{array}{c}30 \\
578^{*}\end{array}$ & $\begin{array}{r}56 \\
654\end{array}$ & $\begin{array}{l}20 \\
76\end{array}$ & $\begin{array}{r}2,877 \\
254\end{array}$ & $\begin{array}{l}\text { N.S. except for urinary symptoms } \\
\text { N.S. except for all drugs and renal score, } \\
\text { and urinary symptoms and aspirin intake }\end{array}$ \\
\hline
\end{tabular}

* Of these patients 70 took aspirin without any other drug.

N.S. = Not significant.

TABLE II-Details of Patients remaining in Study after Exclusions were made by Sex, Age, Diagnosis, Time of Onset of Symptoms, and Severity of Disease

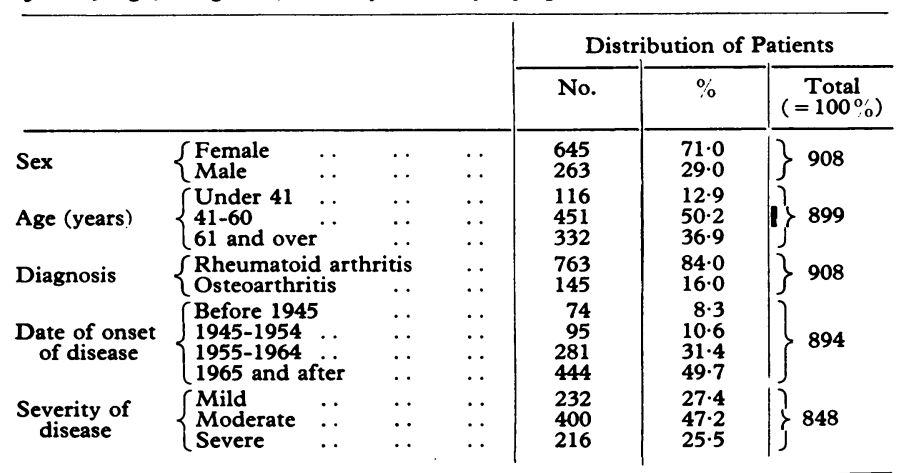

TABLE III-Distribution of Clinical Features among the Rheumatoid Arthritis (R.A.) and Osteoarthritis (O.A.) Patients

\begin{tabular}{|c|c|c|c|c|c|}
\hline & \multirow{2}{*}{$\begin{array}{c}\text { Diagnostic } \\
\text { Group }\end{array}$} & \multicolumn{2}{|c|}{ Males } & \multicolumn{2}{|c|}{ Females } \\
\hline & & $\begin{array}{l}\text { No. } \\
\text { Tested }\end{array}$ & $\begin{array}{l}\text { No. (\%) } \\
\text { Positive }\end{array}$ & $\begin{array}{c}\text { No. } \\
\text { Tested }\end{array}$ & $\begin{array}{l}\text { No. (\%) } \\
\text { Positive }\end{array}$ \\
\hline $\begin{array}{l}\text { Rheumatoid factor } \\
\text { Arteritis } \\
\text { Nodules } \\
X \text {-ray erosions } \\
\text { Recurrent U.T.I. } \\
\text { (history) } \\
\text { Glomerulonephritis } \\
\text { (history) } \\
\text { Loin pain (history) } \\
\text { Haematuria } \\
\text { (history) } \\
\text { Renal stone } \\
\text { (history) } \\
\text { Loss of papilla } \\
\text { (history) } \\
\text { Treated } \\
\text { hypertension } \\
\text { Current U.T.I. } \\
\text { under treatment } \\
\text { Current U.T.I. }\end{array}$ & $\begin{array}{l}\text { R.A. } \\
\text { O.A. } \\
\text { R.A. } \\
\text { O.A. } \\
\text { R.A. } \\
\text { O.A. } \\
\text { R.A. } \\
\text { O.A. } \\
\text { R.A. } \\
\text { O.A. } \\
\text { R.A. } \\
\text { O.A. } \\
\text { R.A. } \\
\text { O.A. } \\
\text { R.A. } \\
\text { O.A. } \\
\text { R.A. } \\
\text { O.A. } \\
\text { R.A. } \\
\text { O.A. } \\
\text { R.A. } \\
\text { O.A. } \\
\text { R.A. } \\
\text { O.A. } \\
\text { R.A. O.A. }\end{array}$ & $\begin{array}{r}213 \\
37 \\
212 \\
39 \\
215 \\
39 \\
209 \\
39 \\
219 \\
41 \\
219 \\
41 \\
219 \\
41 \\
219 \\
41 \\
219 \\
41 \\
218 \\
41 \\
219 \\
40 \\
218 \\
41 \\
263\end{array}$ & $\begin{aligned} & 153(71 \cdot 83) 6(16 \cdot 22) \\
& 11(5 \cdot 19) \\
& 0(0) \\
& 90(41 \cdot 86) \\
& 1(2 \cdot 56) \\
& 158(75 \cdot 60) \\
& 1(2 \cdot 56) \\
& 6(2 \cdot 74) \\
& 2(4 \cdot 88) \\
& 1(0 \cdot 46) \\
& 0(0) \\
& 7(3 \cdot 20) \\
& 3(7 \cdot 32) \\
& 5(2 \cdot 28) \\
& 0(0) \\
& 7(3 \cdot 20) \\
& 0(0) \\
& 0(0) \\
& 0(0) \\
& 7(3 \cdot 20) \\
& 4(10 \cdot 00) \\
& 5(2 \cdot 29) \\
& 2(4 \cdot 88) \\
& 9(3 \cdot 42)\end{aligned}$ & $\begin{array}{l}522 \\
91 \\
520 \\
103 \\
525 \\
103 \\
518 \\
97 \\
537 \\
103 \\
533 \\
103 \\
537 \\
103 \\
534 \\
104 \\
537 \\
103 \\
531 \\
101 \\
531 \\
101 \\
536 \\
103 \\
645\end{array}$ & $\begin{aligned} & 342(65.52) \\
& 5(5.49) \\
& 28(5.38) \\
& 0(0) \\
& 139(26.48) \\
& 1(0.97) \\
& 399(77.03) \\
& 7(7.22) \\
& 69(12.85) \\
& 16(15.53) \\
& 3(0.56) \\
& 3(2.91) \\
& 27(5.03) \\
& 4(3.88) \\
& 19(3.56) \\
& 6(5.77) \\
& 5(0.93) \\
& 0(0) \\
& 2(0.38) \\
& 0(0) \\
& 65(12.24) \\
& 25(24.75) \\
& 24(4.48) \\
& 8(7.77) \\
& 55(8.53)\end{aligned}$ \\
\hline
\end{tabular}

U.T.I.-Urinary tract infection

usage in the past, and the number of months since discontinuance was recorded. Class four indicated continuous dose to the date of completion of the sheet. In classes three and four the average dose and the duration of dosage were recorded to enable computation of the total amount taken. These records were then ranked as shown in table VI. Laboratory data were reconded numerically and other features were graded as $\mathbf{0}$ not recorded, 1 negative, 2 doubtful abnormality, and 3 definite abnormality. Grades 1 and 2 were regarded as negative in the analysis.

The scoring system (table VI) was modified from that originally suggested (Wigley, 1971) to increase the detection of renal disease except for the blood urea component, which
TABLE IV-Mean Blood Biochemical Values \pm S.D.

\begin{tabular}{|c|c|c|c|c|}
\hline & \multicolumn{2}{|r|}{ Males } & \multicolumn{2}{|r|}{ Females } \\
\hline & $\begin{array}{l}\text { No. } \\
\text { Tested }\end{array}$ & Blood Value & $\begin{array}{l}\text { No. } \\
\text { Tested }\end{array}$ & Blood Value \\
\hline $\begin{array}{l}\text { Uric acid }(\mathrm{mg} / 100 \mathrm{ml}) \\
\text { Urea (mg } / 100 \mathrm{ml}) \\
\text { Chloride }(\mathrm{mEq} / \mathrm{l}) \\
\text { Bicarbonate }(\mathrm{mEq} / 1 .) \\
\text { Creatinine }(\mathrm{mg} / 100 \mathrm{ml})\end{array}$ & $\begin{array}{l}252 \\
258 \\
218 \\
197 \\
199\end{array}$ & $\begin{array}{cc}5.74 & \pm 1.79 \\
38.74 & \pm 12.71 \\
102.78 & \pm 4.26 \\
26.26 & \pm 3.36 \\
0.995 & \pm 0.330\end{array}$ & $\begin{array}{l}603 \\
632 \\
532 \\
491 \\
509\end{array}$ & $\begin{aligned} 4.92 & \pm 2 \cdot 10 \\
34 \cdot 81 & \pm 13 \cdot 14 \\
102 \cdot 69 & \pm 5 \cdot 18 \\
25 \cdot 88 & \pm \\
0.849 & \pm 0 \cdot 340\end{aligned}$ \\
\hline
\end{tabular}

U.T.I. = Urinary tract infection.

TABLE v-Proportion of Patients in whom Urine Examination gave Abnormal Results

\begin{tabular}{|c|c|c|c|}
\hline \multicolumn{2}{|c|}{ Abnormal Result } & No. Tested & $\begin{array}{c}\text { No. (\%) with } \\
\text { Abnormal Result }\end{array}$ \\
\hline $\begin{array}{l}\text { White blood cells } \geqslant 5 / \text { H.P.F. of } \\
\text { Red blood cells } \geqslant 2 / \mathrm{H} . \text { P.F. or } \\
\text { Casts } \geqslant 2 / \mathrm{H} . P . F . \\
\text { Colony Count } \geqslant 10,000 / \mathrm{ml} \\
\text { Protein }+ \text { or more } \quad . \\
\text { Sugar }+ \text { or more } \quad . .\end{array}$ & $\begin{array}{l}\text { or } \begin{array}{c}>5,000 / \mathrm{ml} \\
>2,000 / \mathrm{ml}\end{array} \\
\cdots \\
\cdots \\
\cdots \\
\cdots\end{array}$ & $\begin{array}{l}871 \\
861 \\
739 \\
818 \\
862 \\
847\end{array}$ & $\begin{aligned} 118(13 \cdot 5) \\
63(7 \cdot 3) \\
20(2 \cdot 7) \\
177(21 \cdot 6) \\
83(9 \cdot 6) \\
18(2 \cdot 1)\end{aligned}$ \\
\hline
\end{tabular}

H.P.F. = High-power field.

was often raised without relation to analgesic intake. A blood urea above $40 \mathrm{mg} / 100 \mathrm{ml}$ was given a score of 3 only if one or more other features were present. This gave a score of 8 or more in 23 out of 26 patients diagnosed by a nephrologist (R.B.M.) as having analgesic nephropathy. The data on the three cases scoring less than 8 were incomplete as the patients were first seen in terminal renal failure. The sensitivity of the method was considered to be acceptable. The five patients with definite or probable necrosis in this study (see below) all scored more than 7 points. Specificity was not high, however, as some patients with renal disease not attributable to analgesics scored more than 7.

\section{Results}

As $\chi^{2}$ analyses of ranked total drug intake and average daily dose in relation to both total renal score and the separate features contributing to the score gave negative results the

TABLE VI-Components of Renal Score shouring Values Assigned and Frequency of Each Feature

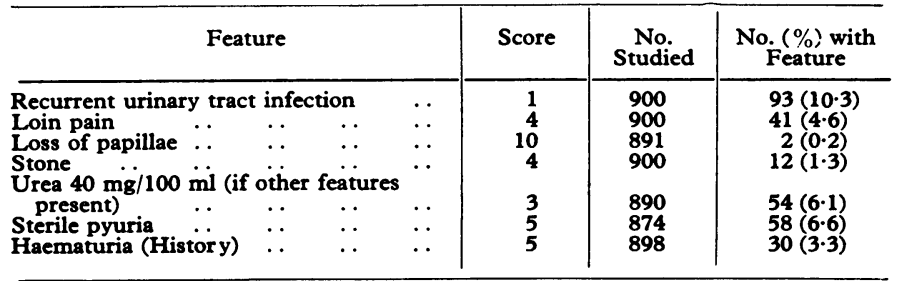


possibility arose that a true association between drug intake and total renal score at low frequency was being obscured by irrelevant renal disease. Thus data sheets showing renal abnormality were reviewed (by R.B.M. and R.D.W.) and further information was requested. Diagnoses were then made in the normal clinical manner. Though this approach was not objective it took note of features not in the score, panticularly time relationships in the history and pyelographic findings. Of the initial 925 patients 17 were excluded as they were considered to have had unrelated renal disease. There was one case each of the following conditions: hydronephrosis, bladder neck stenosis, nephritis, liquorice ingestion with pyelonephritis, and haematuria and recurrent urinary tract infection in a patient who had not taken analgesics. Out of 16 patients with renal stone 10 were excluded as symptoms preceded analgesics, but six in whom time relationships allowed the possibility of analgesic nephropathy were included as passage of a papilla could have simulated stone. Patients with the following disorders were not excluded as the disorder was possibly relevant to analgesics: haemorrhage cystitis, chronic pyelonephritis, haematuria attributed to gold, carcinoma of the bladder, and hypertension with red cells and casts.

Four patients showed clear evidence of papillary necrosis. Three had taken more than $1 \mathrm{~kg}$ of aspirin in the form of aspirin, phenacetin, and codeine tablets. Of these, two had passed papillary material and the other showed typical changes on the pyelogram. In the founth patient the history and pyelographic appearances were typical but he had not passed a papilla. He had taken $8 \mathrm{~kg}$ of aspirin together with $0.6 \mathrm{~kg}$ of phenylbutazone till changing to indomethacin $50 \mathrm{mg} /$ day for the last year $(0.018 \mathrm{~kg})$. An elderly woman dying in renal failure with uniformly shrunken kidneys had taken a high dose of aspirin $(100 \mathrm{mg} / \mathrm{kg} /$ day $)$ for 10 years with $12 \mathrm{~kg}$ of paracetamol. Pyelography was not feasible and necropsy was refused. She was classified as having probable analgesic nephropathy.

In this analaysis acetylsalicylic acid, sodium salicylate, soluble aspirin, enteric-coated aspirin, and aloxiprin are grouped and referred to as aspirin (group A, table VII). None of the 44 patients taking more than $1 \mathrm{~kg}$ of aspirin with no other drug was considered to have had analgesic nephropathy. After the exclusion of the cases listed above $\chi^{2}$ analysis suggested a significant relation between renal score and aspirin intake alone or in any combination (groups $\mathrm{A}+\mathrm{B}, \chi^{2}{ }_{12}=$ $22.9, P=0.03$ ) but the distribution of the components of $\chi^{2}$ did not indicate a causal relationship. This question was posed more directly by comparing scores of up to 8 and over 8 with aspirin intakes $(A+B)$ of up to $1 \mathrm{~kg}$ and over $1 \mathrm{~kg}$. The answer was negative $\left(x^{2}=0.58, P=0.45\right)$ and the correlation coefficient was very low $(0.05)$, so it was concluded

TABLE vII-Number of Patients in Each Drug Intake Rank for all Drugs. Figures in Parentheses indicate Equivalent Amounts based on Usual Dosage

\begin{tabular}{|c|c|c|c|c|c|c|}
\hline \multirow{2}{*}{ Group } & \multirow{2}{*}{ Drug } & \multicolumn{5}{|c|}{$\begin{array}{c}\text { kg of Aspirin or Equivalent } \\
\text { Amounts }\end{array}$} \\
\hline & & 0 & -1 & -2 & -5 & $>5$ \\
\hline \multirow{8}{*}{$\begin{array}{l}\mathbf{A} \\
\mathbf{A} \\
\mathbf{B}+\mathbf{B}\end{array}$} & $\begin{array}{l}\text { Aspirin }(1 \mathrm{~kg}) \\
\text { E.C. A pirin }(1 \mathrm{~kg})\end{array}$ & $\begin{array}{l}415 \\
806 \\
563\end{array}$ & $\begin{array}{r}206 \\
77 \\
153\end{array}$ & $\begin{array}{l}74 \\
16 \\
47\end{array}$ & $\begin{array}{r}104 \\
6 \\
33\end{array}$ & $\begin{array}{r}109 \\
3 \\
12\end{array}$ \\
\hline & Aspirin aloxiprin and E.C. & 2,75 & 267 & 101 & 128 & 137 \\
\hline & $\begin{array}{l}\text { APC (1 kg aspirin content) } \\
\text { Total of aspirin, E.C. aspirin, }\end{array}$ & 832 & 44 & 11 & 19 & 2 \\
\hline & zontent & 254 & 269 & 103 & 139 & 143 \\
\hline & $\begin{array}{l}\text { Paracetamol }(1.5 \mathrm{~kg}) \\
\text { Butazones }(100 \mathrm{~g})\end{array}$ & $\begin{array}{l}704 \\
574\end{array}$ & $\begin{array}{l}151 \\
210\end{array}$ & $\begin{array}{l}21 \\
46\end{array}$ & $\begin{array}{l}29 \\
36\end{array}$ & $\begin{array}{r}3 \\
42\end{array}$ \\
\hline & Indomethacin $(25 \mathrm{~g})$ & 291 & 265 & 90 & 146 & 116 \\
\hline & $\begin{array}{l}\text { Fenamates }(400 \mathrm{~g}) \\
\text { Steroids }(1,000 \text { tablets })\end{array}$ & $\begin{array}{l}844 \\
693\end{array}$ & 58 & 31 & 47 & 79 \\
\hline & & 0 & -2 & -5 & -8 & $>8$ \\
\hline $\mathbf{H}$ & All drugs combined & 43 & 319 & 182 & 119 & 245 \\
\hline
\end{tabular}

E.C. Aspirin = Enteric- coated aspirin. that this was not a causal relationship. This analysis again gave a negative result after subtracting aspirin taken with phenacetin (groups $\mathrm{A}-\mathrm{B} ; \chi^{2}{ }_{9}=17.9, \mathrm{P}=0.04 ; \chi^{2}=0.02$, N.S.).

When all analgesic groups were combined in the equivalent amounts shown in table VII (group $\mathrm{H}$ ) a significant association was shown $\left(\chi^{2}{ }_{9}=19.4 ; \mathrm{P}=0.04 ; \chi^{2}=8.3, \mathrm{P}<\right.$ 0.01 ) between scores of up to 8 and over 8 and intakes of up to $1 \mathrm{~kg}$ and over $1 \mathrm{~kg}$, suggesting a causal relationship, but the correlation coefficient of score on aspirin dosage was low at 0.09 , so that though the effect was significant it was very small in degree. Separate analysis of the component groups showed no association except for indomethacin $\left(x^{2}=8.1 ; \mathrm{P}\right.$ $<0.05$ ) above and below $25 \mathrm{~g}$, but this association was negative, with cut-off points at zero and $125 \mathrm{~g}$. Separate analysis of APC takers did not show a significant association between intake and score though including three definite cases attributed to this cause in the clinical assessment. These analyses were repeated without making exclusions, as the manner in which cases were excluded would apply a bias towards showing an association. This did not affect the conclusions drawn. Blood urea, though the mean and standand deviation was higher than the generally accepted normal values, did not relate to any of the drugs taken or to diagnosis, severity or duration of disease, age, or sex. The Rangiora survey levels were $10 \mathrm{mg} / 100 \mathrm{ml}$ lower than those found in the clinic patients in all decades. This could be pantly explained by the Rangiora subjects having provided fasting blood samples (Beaven et al., 1974). Serum creatinine conformed to accepted normal levels and was not correlated with aspirin intake. Though regression analysis shows that blood urea does relate to oreatinine the effect is small, so that the increase in blood urea may be pantly related to an unidentified factor independent of glomerular filtration.

Of more than 500 other associations tested most of those significant were not related to the main problem. There was a negative association between haemoglobin and aspirin attributable to the severity of disease and or occult blood loss or both and a negative association between uric acid level and aspirin explained by the uricosuric effect of high-dose aspirin.

An association between all aspirin intake (groups $\mathbf{A}+\mathbf{B}$ ) and a history of urinary tract infection $\left(\chi^{2}{ }_{4}=15.8, P<0.01\right)$ could not be explained by the large number of women in the study as it was still significant for women under 50 years of age $\left(x_{2}^{2}=9.3, P<0.01\right)$ and the mean ages of those taking more than $1 \mathrm{~kg}$ of aspirin and up to $1 \mathrm{~kg}$ did not differ significantly (56.0 and 54.9 years respectively). After the exclusion of the APC takens aspirin dosage was still associated with urinary tract symptoms $\left(x^{2}=6.58, \mathrm{P}<0.025\right)$.

Gastric side effects were assessed by patients' recall only, so that the actual frequency would have been underestimated. Some $20 \%$ gave a history of gastric intolerance of aspirin. Altogether 48 patients had had either a gastrointestinal haemorrhage or an ulcer; 13 attributed this to aspirin, 13 to another drug, and 17 to aspirin and another drug. In five cases no drugs were blamed.

\section{Discussion}

In this study no associaion was found between aspirin intake and a score of renal dysfunction designed to deteot analgesic nephropathy. As the patients were not allocated at random to treatment groups a true association could have been obscured bv other variables, but none was found. Though there was a wide variation of aspirin intake in this large sample the possibility remains that renal damage can result from aspirin ingestion but with such infrequency and such slight severity that it cannot be shown. Much reliance is placed by nephrologists on pyelography for detecting papillary 
necrosis (Lindvall, 1960). It could be argued that all subjects should have had pyelography to increase the likelihood of deteation, but this was not feasible. The association between aspirin consumption and a history of urinary tract infection concurs with the findings of Waters et al. (1973) in a population sample. In both studies the pant played by other analgesics was not clear, and funther study is needed to clarify this point.

Since detailed renal function tests might have detected analgesic nephnopathy at an early stage a subsample of 40 cases and controls was tested in Palmerston Nonth but no relation between renal function and aspirin dose was shown, as with 66 cases studied by Jeremy et al. (1972) and 97 cases studied by Burry, 1972).

Searching the data by hand to find cases of analgesic nephnopathy not apparent in the general analysis disclosed four definite cases and one probable case, in which the patient took paracetamol with aspirin. These diagnoses could have been biased in not allowing for changes occurring in the absence of aspirin intake, as is the case with isolated published reponts, so that coincidence could not be disproved. There was, however, no definite evidence of papillary necrosis in those not taking aspirin. If there was a real association between aspirin alone and renal disease more than the few reponts of this association would be expected in the world literature.

Nephnologists in New Zealand were asked to provide details of patients with analgesic nephropathy referred to their clinics taking aspirin alone for anthritis but none were reponted. A patient with lupus erythematosus who took a large amount of aspirin with steroid over seven years developed definite papillary necrosis but there were also the renal changes of lupus erythematosus.

Though in each of three of the definite cases of analgesic nephropathy the patient had taken more than $3 \mathrm{~kg}$ of APC 11 patients with scores of below 5 had taken even greater amounts, two of these taking more than $6 \mathrm{~kg}$. As only 32 patients took more than $1 \mathrm{~kg}$ failure to show significant association between APC and renal score does not cast doubt on the generally held view that excessive use of APC does cause analgesic nephropathy. An extension of this study in progress in Brisbane (Ferguson et al., 1974) using a comparable protocol may clarify the role of the APC preparations, as analgesic nephropathy is reported to be frequent in Brisbane (Burry et al., 1966). The recent removal of phenacetin from some proprietary preparations in Australia may help to define the role of this drug. One probable case of analgesic nephropathy in this study was attributed to aspirin and paracetamol, and in one definite case the patient took aspirin with phenylbutazone and later indomethacin. Though there was an association of minor degree between all drugs and renal score none of the component gnoups was clearly related, so that it is possible that combinations of analgesics are more likely to cause renal damage than single drugs. This may be an additive effect as more analgesic is taken, 546 patients taking more than $2 \mathrm{~kg}$ of aspirin or equivalent in this study. Though this is relevant to one of the questions asked in the protocol some chance associations apparently significant at the $1 \%$ level were inevitable when such a large number of tests were made on one set of data. There is little evidence in the literature that these drugs affect the kidney when used separately in therapeutic doses. There is only one case repont of papillary necrosis attributed to phenylbutazone (Morales and Steyn, 1971). This was of a patient who had had a nephrectomy for stone, and the association may have been coincidental.
The high frequency of papillary necrosis reponted in rheumatoid anthritics examined after death (Clausen and Pedersen, 1961; Lawson and McLean, 1966; Nanra and Kincaid-Smith, 1970) may reflect the severity of the anthritis and a high intake of APC. Only one of these patients was reported to have taken aspirin alone. Berkson's bias would further increase the frequency of concurrence, as the probability of hospital admission and in turn postmontem examination is much greater where there is more than one condition. Large variations in the frequency of analgesic nephropathy in different countries would be expected as the pattern of drug availability and promotion varies widely, and the risk is said to be greater in warm climates (Burry, 1967).

Though most of the $20 \%$ who had dyspepsia from aspirin discontinued the drug $9 \%$ of the regular aspirin takers reported peptic ulcer or gastric haemorrhage or both. This may not be higher than expected in the general population and funther study is indicated.

\section{Conclusion}

This study shows that nearly all patients supervised in rheumatic diseases clinics in New Zealand can take large amounts of aspirin alone or with other drugs without renal damage. If there is a risk from aspirin alone it must be of a low onder and is unlikely to affect a decision to prescribe aspirin and its variants. Periodic checks on urine deposits, however, are recommended for patients maintained on a high dose for a long period and any renal symptoms should be investigated. Though no significant association with APC intake was shown the number of patients at risk was small and the findings are consistent with the generally held view that aspirin and phenacetin compound preparations do in large enough doses cause papillary necrosis in susceptible patients (Koutsaimanis and De Wardener, 1970). No clear evidence was found that any of the analgesics separately cause renal damage but it is possible that an additive effect of aspirin and the other constituents of the compound tablets, and possibly other analgesics, is necessary to cause nephropathy.

We thank Mr. George Spears for statistical advice, Massey University for the use of an I.B.M. 1620 computer, and the New Zealand Rheumatism Foundation and the New Zealand Medical Research Council for financial support.

\section{References}

Beaven, D. W., Murray, J., and Laing, K. J. (1974). Unpublished observations.

Burry, A. F. (1967). Nephron, 5, 185.

Burry, A. F., De Jersey, P. and Weedon, D. (1966). Medical fournal of Australia, 1, 873.

Burry, H. C. (1972). Annals of the Rheumatic Diseases, 31, 65.

Clausen, E., and Pedersen, J. (1961). Acta Medica Scandinavica, 170, 631. Consumer, 1972, 82, 36.

Dubach, U. C., Levy, P. S., and Mueller, A. (1971). American fournal of Epidemiology, 93, 425 .

Fergusson, I., Johnson, F. L., and Wigley, R. D. (1974). Study in progress.

Jeremy, R., Steele, T. W., Schapel. G. J., and Edwards, K. D. G. (1972). Australian Rheumati
Abstract 15, p. 12.

Abstract 15, p. 12.
Koutsaimanis, K. G., and De Wardener, H. E. (1970). British Medical fournal, 4, 131 .

Lawson, D. H. (1973). Fournal of Chronic Diseases, 26, 39.

Lawson, A. A. H., and McLean, N. (1966). Annals of the Rheumatic Diseases, 25,441 .

Lindvall, N. (1960). Acta Radiologica; Diagnosis, Suppl. No. 192.

Morales, A., and Steyn, J. (1971). Archives of Surgery, 103, 420.

Nanra, R. S., and Kincaid-Smith, P. (1970). British Medical fournal, 3, 559.

Royal Australasian College of Physicians (1969). New Zealand Medical Fournal, 70, 39.

Sorensen, A. W. S. (1966). Nephron, 3, 366.

Waters, W. E., Elwood, P. C., and Asscher, A. W. (1973). Lancet, 1, 341.

Wigley, R. D. (1971). New Zealand Medical fournal, 74, 301. 